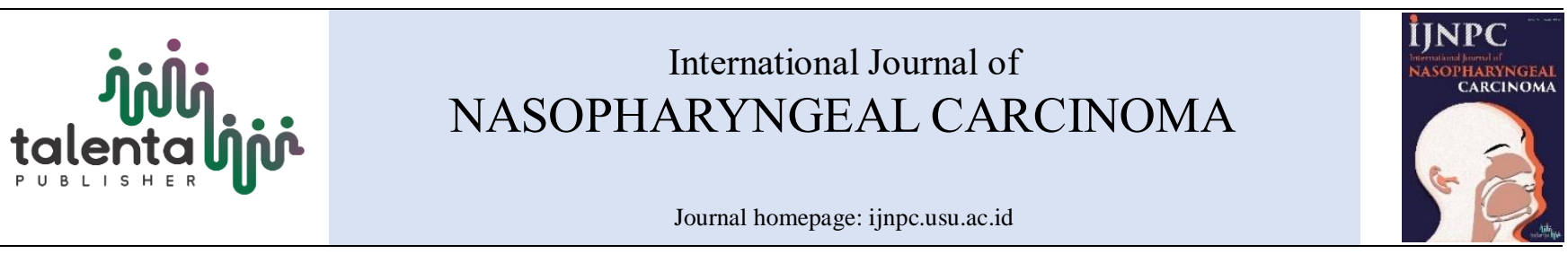

\title{
NASOPHARYNGEAL CARCINOMA CHARACTERISTIC IN ARIFIN ACHMAD HOSPITAL IN JANUARY-OCTOBER 2018
}

\author{
Harianto* \\ Otorhinolaryngological-Head and Neck Surgery department Medical Faculty of Riau University/Arifin Achmad Hospital, Riau Province
}

\section{Abstract}

Introduction: Nasopharyngeal carcinoma was the commonest head and neck malignancy worldwide that was capable to metastatized distantly and potentially relaps. In Indonesia, the prevalence of this cancer was estimated $1.4 \%$ or approximately 347,792 people and the highest found in D.I Yogyakarta, whereas Riau Province was 4,301 people. This is made the nasopharyngeal carcinoma as the 4 th of the most commonest malignancy in Indonesia after the mamae carcinoma, cervix carcinoma and skin tumor.

Objective: The purpose of this study was to asses the characteristic of NPC patient in Arifin Achmad Hospital Riau Province including the incidence, gender,age,histopathology classification,distribution by the age and therapy.

Method: Retrospective cross-sectional approach with the descriptive study to assess the entire population of nasopharyngeal carcinoma based on gender, age, histopathology classification and therapy from January to October 2018. The data was obtained from several units and processed into frequency and distribution table.

Result: The number of the cases that obtained was 137 cases where 62 new cases and 75 old cases. Men were mostly affected and NPC was often found in 40-60 years old. The majority of the histopathology classification in this study was undifferentiated nasopharyngeal carcinoma. Most of the patient was treated with chemotherapy.

Conclusion: NPC was the highest incidence of the head and neck malignancy commonly in men. All the most occured in early elderly and the highest histopathology type was undifferentiated nasopharyngeal carcinoma
\end{abstract} (WHO Type III). Chemotherapy was the choice to treat the patient.

\section{Article Info \\ Keywords:}

Nasopharyngeal carcinoma, patient characteristic, incidence rate, histopathology classification, NPC therapy

\section{*Corresponding author \\ Address: Jalan. Diponegoro No.1, Suka Mulia, Kec. Sail, Kota Pekanbaru, Riau 28133}

e-mail: dr.harianto.tht@gmail.com

\section{INTRODUCTION}

Nasopharyngeal carcinoma (NPC) is the most often primary carcinoma that originated from nasopharynx and capable to metastasize distantly. Nasopharyngeal carcinoma potentially can relapse though radiation already done [1]. Based on GLOBOCAN 2012 (WHO database in estimating all carcinoma incidence, mortality and prevalence), there were 87,000 new cases of nasopharyngeal carcinoma annually $(61,000$ new cases occurring in men and 26,000 new cases in women) with 51,000 deaths due to NPC $(36,000$ in men, and 15,000 in women) $[2,3]$.

The highest incidence worldwide is in Guangdong Province of South China, which is 40-50 cases of nasopharyngeal carcinoma among 100.000 residents. Nasopharyngeal carcinoma is very rare in Europe and North America with an incidence of around $<1 / 100.000$ population $[4,5]$. Nasopharyngeal carcinoma is one of the malignancies that is often found in Indonesia, ranked as the 4 th most carcinomas in Indonesia after mamae carcinoma, cervix carcinoma and skin tumor. Nasopharyngeal carcinoma is the commonest head and neck malignancy $[6,7]$.

In Indonesia, there are 6.2/100,000 with 13,000 new cases. Research conducted at Dr.Cipto Mangunkusumo Hospital in 1996 and 2005, there were 1,121 patients diagnosed with nasopharyngeal carcinoma. In 2010 nasopharyngeal carcinoma stand as the 5th commonest carcinomas [8,9]. Based on Indonesian Basic Health Research's data in 2013, the prevalence of carcinoma in Indonesia was estimated to $1.4 \%$ or around 347,792 people with the highest prevalence found in the Province of D.I. Yogyakarta (4.1\%), whereas Riau Province $(0.7 \%)$ or around 4,301 people. 10 Based on previous research conducted at Arifin Achmad Hospital Riau province in 2009-2013, 92 cases were obtained [11].

The principal program in carcinoma control is cancer registration. Cancer registration is the process of collecting data on each incidence and characteristic of malignancy [12]. But until now there is no specific recording and reporting system for cancer in Indonesia, that is because the recording and reporting incorporate with other diseases.

\section{MATERIAL AND METHODS}

The design of this study is a descriptive study with a retrospective crosssectional approach. The sample including the entire population (total sampling) of nasopharyngeal carcinoma patients based on histopathological examination at Arifin Achmad Hospital from January-October 2018. Collecting data from several places, mainly Electronic Data Processing (EDP), medical record, chemotherapy unit integrated laboratory and pathology anatomy of the Arifin Achmad Hospital. Data on nasopharyngeal carcinoma cases including: medical record number, gender, age, histopathology type and therapy.

\section{RESULT}

Based on the data, the number of cases from january to october 2018 were 137 cases include 62 new cases and 75 old case. Total patients treated as outpatient and inpatient Arifin Achmad hospital in january to october 2018 is 48.232 patients. Based on this data, the prevalence of nasopharyngeal carcinoma at Arifin Achmad hospital during the past 10 months, mainly from january-october 2018 was $0.28 \%$, and the incidence was $0,12 \%$ (Table 1 ).

Table 1. Case of nasopharyngeal carcinoma

\begin{tabular}{rccc}
\hline Years & $\begin{array}{c}\text { New case } \\
\mathbf{n}(\%)\end{array}$ & $\begin{array}{c}\text { Old case } \\
\mathbf{n}(\%)\end{array}$ & $\begin{array}{c}\text { Total } \\
\mathbf{n}(\%)\end{array}$ \\
\hline January-October 2018 & $62(45.2)$ & $75(54.7)$ & $137(100)$ \\
\hline
\end{tabular}

The Distribution of nasopharyngeal carcinoma based on gender all the most by men as $98(71.5 \%)$, whereas women counted to 39 people $(28.5 \%)$. The number of frequencies can be seen in table 2. Nasopharyngeal carcinoma mostly affecting men, compared to women, this is related to the 
factors or lifestyle, habitual that is commonly done by men such as smoking, and alcohol consumption as the risk factors of NPCThe distribution of nasopharyngeal carcinoma based on gender mostly was men as 98 people $(71,5 \%)$, whereas women counted to 39 people $(28,5 \%)$. The frequencies can be seen in table 2. Nasopharyngeal carcinoma mostly affected men, compared to women, this is related to lifestyle such as smoking, and alcohol consuming as the risk factors of NPC $[6,13]$.

Table 2. The Prevalence of nasopharyngeal carcinoma based on gender

\begin{tabular}{lcc}
\multicolumn{1}{c}{ Gender } & Frequency (n) & Percentage (\%) \\
\hline Man & 98 & 71.5 \\
Women & 39 & 28.5 \\
\hline Total & $\mathbf{1 3 7}$ & $\mathbf{1 0 0}$ \\
\hline
\end{tabular}

Based on the 137 cases obtained, the number of nasopharyngeal carcinoma is mostly found in early elderly $(32,8 \%)$. The description of the nasopharyngeal carcinoma patient based on age in the Arifin Achmad hospital can be seen in table 3. It Seems the most cases of nasopharyngeal carcinoma affecting late adulthood and early elderly. In this study, it is very rare in toddlers and children. The data that we found was same with the journal that shows the peak prevalence of nasopharyngeal carcinoma which is 40-60 years, this is one of the risk factors that can develop nasopharyngeal carcinoma..

Table 3. The distribution of nasopharyngeal carcinoma based on the age

\begin{tabular}{|c|c|c|}
\hline Age & Frequency (n) & Percentage (\%) \\
\hline $0-4$ & 0 & 0 \\
\hline $5-11$ & 0 & 0 \\
\hline $12-16$ & 2 & 1.5 \\
\hline $17-25$ & 8 & 5.8 \\
\hline $26-35$ & 19 & 13.9 \\
\hline $36-45$ & 38 & 27.7 \\
\hline $46-55$ & 45 & 32.8 \\
\hline $56-65$ & 18 & 13.1 \\
\hline$>65$ & 7 & 5.1 \\
\hline Total & 137 & 100.0 \\
\hline
\end{tabular}

This study was continued in the departement of Anatomic Pathology where we obtained 62 new cases of nasopharyngeal carcinoma that shows positive histopatology results that will be classified based on the WHO classification. Based on the results of histopathological examination in table 4, undifferentiated nasopharyngeal carcinoma (WHO type III) was the most found type in 38 cases $(61,3 \%)$ of 62 cases. WHO classification for type III nasopharyngeal carcinoma is the most common type and most often occurs [13]

Table 4. Distribution of the new case of nasopharyngeal malignancy according to histopathological type

\begin{tabular}{cccc}
\hline \multicolumn{4}{c}{ Classification of a new case of NPC based on histopathology } \\
\hline $\begin{array}{c}\text { Type I } \\
\mathbf{n}(\boldsymbol{\%})\end{array}$ & $\begin{array}{c}\text { Type II } \\
\mathbf{n}(\boldsymbol{\%})\end{array}$ & $\begin{array}{c}\text { Type III } \\
\mathbf{n}(\boldsymbol{\%})\end{array}$ & $\begin{array}{c}\text { Total } \\
\mathbf{n}(\boldsymbol{\%})\end{array}$ \\
\hline $12(19.4)$ & $12(19)$ & $38(61.3)$ & $62(100)$ \\
\hline
\end{tabular}

From new cases of NPC, histopathological type distribution was based on age, can be seen in table 4.5. From the table, it shows that the WHO type III classification is the most frequent in the early elderly or the range of 46 55 years, which is $16,1 \%$.

Table 5. Distribution of histopathological types based on age

\begin{tabular}{lrrrr}
\hline & \multicolumn{3}{c}{ WHO Classification } & \\
\cline { 2 - 4 } Age Group (years old) & $\begin{array}{c}\text { Type I } \\
\mathbf{n}(\%)\end{array}$ & $\begin{array}{c}\text { Type II } \\
\mathbf{n}(\%)\end{array}$ & $\begin{array}{c}\text { Type III } \\
\mathbf{n}(\%)\end{array}$ & $\begin{array}{r}\text { Total } \\
\mathbf{n}(\%)\end{array}$ \\
\hline Toddler (0-4) & $0(0)$ & $0(0)$ & $0(0)$ & $0(0)$ \\
Child (5-11) & $0(0)$ & $0(0)$ & $0(0)$ & $0(0)$ \\
Early teens (12-16) & $0(0)$ & $0(0)$ & $1(1.6)$ & $1(1.6)$ \\
Late adolescents(17-25) & $0(0)$ & $0(0)$ & $3(4.8)$ & $3(4.8)$ \\
Early adult (26-35) & $4(6.5)$ & $1(1.6)$ & $6(9.7)$ & $11(17.7)$ \\
Late adult (36-45) & $2(3.2)$ & $4(6.5)$ & $9(14.5)$ & $15(24.2)$ \\
Early elderly (46-55) & $4(6.5)$ & $4(6.5)$ & $10(16.1)$ & $18(29.0)$ \\
Late elderly (56-65) & $1(1.6)$ & $3(4.8)$ & $6(9.7)$ & $10(16.1)$ \\
Elderly (>65) & $1(1.6)$ & $0(0)$ & $3(4.8)$ & $4(6.5)$ \\
\hline
\end{tabular}

Based on 137 cases in this study, only 95 patients were recorded in the chemotherapy unit. Meanwhile, 42 cases were not registered to continue NPC therapy at the chemotherapy unit of Arifin Achmad Hospital. This can be caused by the patients refused further therapy, patients were still waiting for health insurance services, patients needed condition improvement, or the patients were dead.
Table 6. Percentage of therapy in cases of nasopharyngeal malignancy

\begin{tabular}{lcc}
\hline \multicolumn{1}{c}{ Type of therapy } & Total $(\mathbf{n})$ & Percentage (\%) \\
\hline Chemotherapy & 86 & 90.5 \\
Chemotherapy & 8 & 8.4 \\
Chemoradiation & 1 & 1.1 \\
\hline Total & $\mathbf{9 5}$ & $\mathbf{1 0 0}$ \\
\hline
\end{tabular}

Radiotherapy is the first choice but has several side effects such as difficulty to swallow, neuroendocrine dysfunction, or hearing loss.14 Although the development of NPC management has benefit as much from the advanced radiotherapy techniques, chemoradiotherapy for NPC patients shows more advantages than just radiotherapy. 15 Research by Guo Ping Shan and in China concluded that combination of radiotherapy treatment with chemotherapy was better than radiotherapy alone.16 Based on table 6, the commonest nasopharyngeal carcinoma therapy in Arifin Achmad Hospital was chemotherapy which is $90,5 \%$. This is because the lack of infrastructure due to damaged radiotherapy devices, most patients use the Social Security Administrator for Health (BPJS) and many patients who come with advanced stages.

\section{CONCLUSION}

The case of NPC still has the highest incidence rate in men. NPC is also common in the early elderly age. Histopathologically, type III WHO is the highest number. The overall information about the therapy of NPC patients at ArifinAchmad Hospital in this study shows that chemotherapy is still the choice according to the conditions when patients come.

\section{REFERENCE}

[1] Tabuchi K, Nakayama M, Nishimura B, Hayashi K, Hara A. Early detection of nasopharyngeal carcinoma. International journal of otolaryngology. 2011;2011.

[2] WHO. Nasopharyngeal carcinoma. Rev cancer Med WHO List Essent Med. 2014:1-9.

[3] Nasional KPK, Indonesia KKR. Pedoman Nasional Pelayanan Kedokteran Kanker Nasofaring. KEMENKES RI; 2017.

[4] Brennan B. Nasopharyngeal carcinoma. Orphanet journal of rare diseases. 2006;1(1):23.

[5] Society AC. About Nasopharyngeal Cancer. 2018

[6] Adham M, Kurniawan AN, Muhtadi AI, Roezin A, Hermani B, Gondhowiardjo S, et al. Nasopharyngeal carcinoma in Indonesia: epidemiology, incidence, signs, and symptoms at presentation. Chinese journal of cancer. 2012;31(4):185.

[7] Adham M, Kurniawan AN, Muhtadi AI, Roezin A, Hermani B, Gondhowiardjo $\mathrm{S}$, et al. Nasopharyngeal carcinoma in Indonesia: epidemiology, incidence, signs, and symptoms at presentation. Chinese journal of cancer. 2012;31(4):187-9.

[8] Nasional PK. Rumah Sakit Dharmais. Statistik Kanker.

[9] Indonesia DKR. Situasi penyakit kanker. 2015.

[10] Diniati A, Fidiawati WA, Harianto H. Distribusi Keganasan Nasofaring Berdasarkan Pemeriksaan Histopatologi pada Rumah Sakit di Kota Pekanbaru Tahun 2009-2013. Jurnal Online Mahasiswa Fakultas Kedokteran Universitas Riau.3(1):1-18.

[11] Nasional PK. Rumah Sakit Dharmais. Registrasi Kanker.

[12] Lee KJ, Maniglia AJ. Essential otolaryngology: head \& neck surgery: McGraw-Hill, Medical Pub. Division; 2008.

[13] Hong J, Tian J, Han Q, Ni Q. Quality of life of nasopharyngeal cancer survivors in China. Current oncology. 2015;22(3):e142.

[14] Ng WT, Chang AT, Lee SW, Sze HC, Lee AW. Chemotherapy for nasopharyngeal cancer: neoadjuvant, concomitant, and/or adjuvant. Current treatment options in oncology. 2015;16(9):44.

[15] Shan G-P, Wang B-B, Zhang P, Du F-L, Yang Y-W. Efficacy and Safety of Chemotherapy Combined with Stereotactic Radiotherapy in the Treatment of Nasopharyngeal Carcinoma. Medical science monitor: international medical journal of experimental clinical research. 2017;23:5630 